\title{
Improving Lecturers' Performance through Effective Learning at Department of Islamic Education at Faculty of Islamic Education and Teacher Training IAIN IB Padang
}

\author{
Zulvia Trinova \\ Department of Islamic Education, Faculty of Islamic Education and Teacher Training \\ IAIN Imam Bonjol Padang, Indonesia \\ E-mail : Zulvia.trinova12@gmail.com
}

Received: $11^{\text {th }}$ June 2015; Revised: $18^{\text {th }}$ July 2015; Accepted: $24^{\text {th }}$ July 2015

\begin{abstract}
The aim of this study is to describe the work situation variables, achievement motivation on the performance of Islamic education (PAI) lecturer in creating effective learning in the Department of PAI. This study is a combination of quantitative and qualitative methodss (mixed methods) obtained from observation, questionnaire, interviews, and documentation. The data were analyzed through statistics. Qualitative data were analyzed by using data reduction, categorization, and data verification and conclusions. The working athmosphere contributes $48.7 \%$ to the influence on the lecturer performance work and the motivation contributes $43.0 \%$ to the impact on the lecturer performance. Work situation and achievement motivation respectively affect the work performance of $58.3 \%$. Learning approach used is expository approach, the inquiry, and emotional approach. It was also used PAKEM approach and an approach that is Andragogy. The learning method applied in this research is multi method in the form of active active learning. PAI lecturers used printed media, dicussion paper, and electronic media.
\end{abstract}

Keywords: Effective learning, PAI, performance.

How to Cite: Trinova, Z. (2015). Improving Lecturers' Performance through Effective Learning at Department of Islamic Educations at Faculty of Tarbiyah and Teacher Training IAIN IB Padang. Al-Ta Lim, 22(3). doi:http://dx.doi.org/10.15548/jt.v22i3.129

Permalink/DOI: http://dx.doi.org/10.15548/it.v22i3.129

\section{INTRODUCTION}

In the era of globalization, human resources is one of the factors that plays an important role in an organization in achieving its objectives. The success of the organization in carrying out its management is determined by the role of the human resources capability, skill and education. Therefore, human resources need to be given the motivation and work reward for them, so that it can increase productivity that can be proved from their performances
Work performance is what is being said or what is done by a person. Job performance has an important role in improving the quality of an institution. According to Steers (2000) factors that can affect a person's work performance is the ability, motivation, attitudes, interests, and the willingness of the accepted work. Anoraga (2002) argues that there are several factors that can affect a person's work performance, namely capabilities or skill, work passion, wages (incentive), security and work protection, knowledge of management, 
environment and the atmosphere of the team work, the expectations of career development, the involvement in organizational development, attention and leadership of the boss. Mitrani (2005) says there are other factors that can also affect the expected performance of the person, namely, responsibility, freedom, labor standards, supervision, and its motivation.

Thus, it can be seen that a lot of things that can increase a person's performance at work. However, no matter how good the attractiveness of jobs, their salaries and incentives, lack of security and protection work, but the success of an institution still depend on one's own work performance, whether they have the motivation to work and a desire to improve the quality of institutions.

Learning is a systematic and systemic activity (process) consisting of many components. Each component should not be partial (separate), but should be run regularly, interdependently, complementarily and sustainably (Ramayulis, 2006). In other words, if one component is not going well, the other components will be disrupted. As a result, it will disturb the education process.

Educators and learners is a combination of the two elements that can generate educational interaction by utilizing the material as a medium. all components of teaching there are played optimally in order to achieve the goal of teaching that has been set before instruction executed (Djamarah, 2006). The application of all components of teachingcorrectly will lead to the production of effective learning.

Effective learning is a learning process that can be understood by learners perfectly and also it can sustains in students' memory. and they can apply it Popham, et al., 1992). There are some indicators to see whether learning was effective or not. these can be seen from the criteria or characteristics of effective learning as follows:

1. Effective Learning 'facilitates learners learn' something useful such as facts, skills, values, concepts and how to live in harmony with each other, or to achieve the desired learning outcomes.

2. Effective learning is that the skills obtained are admitted by the competent judge such as educators, supervisors, and tutors ( Wrag, et al., 1996)

In relation to the above theory, it can be said that the success of learning, especially learning Islamic education, of course, cannot be separated from the activity of teaching learning that is the application of learning component to achieve the learning objectives.

In achieving effective learning, the role of leader is needed to create good communication with educators in order to obtain a positive spirit of work. Beside having the good character of a leader, it is also needed the knowledge of each individual caharacteristics and their proficiency in behavior because each person will have a different motivation in working. It depends on the factors of authority, ambition, and education. If a leader does not have a ability to recognize the character of his lecturers at his institution, then it certainly can inhibit creativity and achievement of the lecturers.

The work atmosphere is everything that is around the lecturers that can affect him in carrying out the task. A conducive and enjoyable situation at work can affect the performance of the lecturers. The good working situation can be seen from the physical condition of the working room or non-physical conditions that exist in campus, such as the relationship among the lecturers or the good relationship between the leadership and lectures. The positive situation can certainly improve the quality of job performance of the lecturer in campus.

In an educational institution, providing the good or not good working atmosphere will affect the lecturers quality and performance that also can be seen from the lecturers'motivation in teaching and educating in campus.

Lecturer's motivation for getting an achievement would not have been obtained, if they do not have the maturity psychologically. 
Motivation is a vital element in an institution. Motivation can be interpreted as an attempt to make someone accompalishes his/her job passionately, because he/ she wants to do it.

As Allah says in Surah al-Ra'du verse 11:

For each one are successive [angels] before and behind him who protect him by the decree of Allah. Indeed, Allah will not change the condition of a people until they change what is in themselves. And when Allah intends for a people ill, there is no repelling it. And there is not for them besides Him any patron.

Surah ar-Ra'du verse 11 above is describing about a change. in the context of Quraish Shihab changes (2002) highlighted three main points, namely:

1. The values are embraced and internalized by the community.

2. The inside man, the determination and willpower.

3. The physical and non-physical abilities.

Basically, the changes that happen to each individuals differ from one another. They will gain a success that they created on their willingness and their ability. Thus, it is understood that Islam teaches his people about the importance of motivation in doing any kinds of activity.

Based on the explanation above, it shows that someone will have a good performance with high motivation when they want to get something. Thus, they can make it happen by giving a high performance in teaching on campus.

By looking at the number of indicators that can affect the performance of the lecturer, it is necessary to study the influence between two variables with lecturers' work performance, namely the the working situation in the campus and the lecturer's motivation to obtain an achievement in college. Thus, the achievement of effective learning should be taking into account in regarding to the various components in the learning.

This research is conducted because of various conditions encountered in the Department of PAI the Faculty of Islamic Education and Teacher Training in IAIN Imam Bonjol Padang. For example like the lecturers who are lack of discipline in teaching, coming late and finishing the class earlier than it is supposed to.It was also found that lecturers who came and filled the attendence list at the supervisor, yet they did not teach in the classroom because they had some side jobs. Furthermore, senior lecturer requested junior lecturer/assistant to go to class without being accompanied. Then, having to fill the attendance in the afternoon made the lecturers returning to campus just to take the attendance, although in fact there are no more hours of teaching, counseling for students, and etc.

More over, lecturers often utilize the campus hours for personal needs. In other word, there is a lecturer who is not in teaching hours doing a personal errands. It is not really a big problem, provided that it does not interfere the teaching hours and the consultign times for students on campus. Another example, it also found that the work that has been completed was not carefuly done; it was often late, and it did not fully finished,such as in completing the task in making reports of the lecturers' performance. In the teaching learning process, the approach taken by the lecturer to help the students sometimes do not give positive effects; Then, learning methods and instructional media used were sometimes less varied. These indicate the quality of work is less achieved, and the quantity was not in line with the expectations of the faculty. Such conditions would greatly affect the mood of lecturers in doing their activities on campus .Thus, this can make the lecturers lack of motivation in achievement.

\section{Effective Learning}

Learning is "a structured combination that includes elements of human, material, 
facilities, equipment and procedures that affect each other in achieving the learning objectives. Human beings are involved in the teaching system consisting of learners, teachers, and other personnels such as laboratory personnel. Materials include books, blackboards and chalk, photography, slides and films, audio and video tape. Facilities and equipment consist of classrooms, audio-visual equipment, and computer. The procedure includes the schedule and the method chosen in delivering the information, practice, study, exams and so on ( Hamalik, 2003).

Surya (2003), states that learning is a process that is conducted by an individual to obtain a new behavior changes as a whole as a result of the individual's own experience in the interaction with his/her environment. Furthermore, it can also be known that learning is comprised into several components, namely, goals, methods, materials, media, educators, students, facilities and infrastructure which influence each other in achieving the learning objectives. In this learning process, the interaction occurs between learners as subjects of learning and educators as teachers who interact in the teaching learning process. From this process, there will be a change in the behavior of the individual, the learners.

Based on the above definition, it can be concluded that learning is a process of delivering learning materials/knowledge from a teacher to his students in a systematic way and in a well planned in order that the material/subject matter presented is acceptable by the students so that the learning objective can be achieved effectively.

Effectiveness in each person point of view has a different meaning. It depends on the viewpoint and interests of each person. Effectiveness is the compatibility between people who carry out the task and the intended target (E. Mulyasa, 2003). Effectiveness is also related to the issue of how the achievement of objectives or results obtained, the usefulness or the benefit from the results obtained, the level of the element or component functions, and the level of user satisfaction problems. Meanwhile, The concept of the learning effectiveness is how to take advantage of all the teaching component as well as possible in order to reach the desired teaching objectives.

Learning effectiveness can be achieved if all the elements and components in the learning system function in accordance with the goals and objectives set. Also, Learning effectiveness can be achieved if the design in the preparation, implementation, and the evaluation can be carried out according to the procedure and their respective functions.

\section{Job Performance}

The term of work performance in the General Dictionary of Indonesian, according to Ministry of Education (2001) is derived from the performance which is termed also as the performance that has definition as (1) something that is achieved, (2) the achievements obtained, and (3) work performance. According to Benton (1974) which says that the performance is a process of one's actions. So, basically the performance is the act of doing something that is desired by an individual for a particular outcome.

According Siagian (2005), one can improve his performance by: (a) paying attention to the quality of work; (B) having the creativity and innovation in the work; (C) having a greater responsibility; (D) being able to take decisions, in accordance with the tasks and each duties; (E) getting reward like financial, material or non material; $(\mathrm{F})$ having disciplin and punctual in performing the task.

One's work performance are determined by his ability in developing himself, as quoted by Simamora (2005), that person's attempt to develop himself can improve his performance competence.

Based on those opinios, it can be concluded that the performance is the act of doing something that is desired to get the expected objectives. Work performance is an 
act done by someone in his activities that are influenced by various factors, internal and external factors. Arikunto (2000) explains that internal factors include attitudes, interests, intelligence, motivation, and personality. While external factors are the nature of leadership, facilities, infrastructure, incentives, the athmosphere and the environment of working.

Based on the opinion expressed above, then operationally in this study, the definition of lecturer's work performance is the quality of the three responsibilities of higher education; the ability to perform teaching activities, timeliness in completing the work, and responsibility in carrying out the work. To improve the performance of the lecturer, it is necessary to review how outstanding lecturer's motivation and the work athmospehere created in the Faculty of Education and Teaching in IAIN Imam Bonjol Padang.

\section{Achievement Motivation}

Motivation comes from English: "Motive" which means moving or giving energy stimulation so that people who are given the motivation move actively in accordance with the intended meaning. Hasibuan (2003) states in Latin that the motivation termed "movere" which means impulse or motive power.

Motivation is an internal condition that is specifically direct the behavior of a person to a certain destination. Achievement is interpreted as a success after preceded by an effort. Achievement is an encouragement to overcome obstacles, doing the powers, struggling to do something difficult as well as and as quickly as possible.

Furthermore, Manullang (2004) provides a definition of motivation as " a power stimulants or impetus, which stimulate, encourage someone to master something so it can work with a different from each other. This difference is caused by the difference in motivation, goals and needs of each lecturer, and also because of differences in time and place. "

Wijaya (2006) states that "Motivation is the difference between implementablility and the willing of implemeting. In a closer look, Motivation can be regarded as the willingness to do something to achieve the goal. Motivation is the force, both from within and from outside of oneself that encourages him to achieve the certain goals . In other words, the motivation can be defined as a mental force to the individual or persons as members of the community."

Based on the defintion of the motivation above, it can be understood that the motivation can increase achievement motivation lecturers so it can increase their productivity. Here, the leader had significant role as the motivator to the lecturers which is a basic attempt to influence and direct the lecturers to achieve the objectives of the institution.

The definition of achievement motivation according to Waseso (2006) is " a passion or a desire to do everything as well as possible, not for the sake of obtaining social rewards or prestige, but rather to achieve satisfaction in the mind of individuals".

Based on the opinion above, the indicator of a good achievement motivation is the need of every individual to obtain achievement, power, and affiliation.

With the need for each lecturers to obtain achievement, the desire for power, and the desire to affiliate in completing any works on campus, it can affect their performance in work at the Department of PAI the Faculty of Islamic Education and Teacher Training in IAIN Imam Bonjol Padang.

\section{Working Situation}

According to Timpe (2003), the working situation is a series of nature and the working environment that can be measured based on the perceptions of individuals who work in that environment. Nitisemito also 
states that (2002), the working situation is everything that is around a person that can affect him in carrying out the task. According to Danim (2004), the working situation is a working environment that can generate motivation. Beside the style of leadership and the individual's own attitude, people can work well if there are supporting factors. Meanwhile, a person can become frustrated if the supporting factors are not available. Furthermore it is said that the working situation influence and shape the human capacity. Humans will also behave in accordance with the circumstances surrounding them.

According to Milton (1981), the characteristics of the work situation consists of: (1) work variation, (2) autonomous work, (3) the working identity, (4) feedback, and (5) the importance of the task. Steer and Roders in Griffin (1987) states that the working situation can be seen from: (1) the working field, (2) the level of working, (3) suppression task, (4) a big working group, (5) the leader style, (6) workers relations, and (7) the opportunity to advance.

According to Gibson, Ivancevich, and Donnelly (1992), to measure the working situation, it can be seen from the nature of working, namely, by looking the perceptions on: (1) the structure of work , the variety and task identity, (2) the depth of the work that is autonomous work, and (3) networking, that relationships with others and the chance of making friend.

Lecturers will work optimally when supported by a conducive working situation. With a pleasant working situation, it is expected that it can be a motivation for the lecturers to produce a good work performance. It is clear that the working situation is essential to improve their work performances. Based on that opinion, it can be seen that the indicator in work situations variable, which are related to the nature of working and the physical working environment.

A conducive working situation can create the mood of the persons becoming ease and comfort. Thus it can arise the desire and motivation of lecturer in performing the work assigned so that they can work well and optimally. It means that employees can be said having a good performance in the Department of PAI at the Faculty of Islamic Education and Teacher Training in IAIN Imam Bonjol Padang.

\section{METHOD}

This study used mixed methods between quantitative and qualitative methods. This research was carried out simultaneously and complementarily overview of research results, both quantitatively and qualitatively.

In this study, the primary data were derived from the distribution of questionnaires, observations, and interviews with the respondents (lecturers) of Department of PAI at the Faculty of Islamic Education and Teacher Training in IAIN Imam Bonjol Padang.

It also carried out by collecting secondary data obtained from the guide books, literature, and other written sources that can be used as a source of data associated with the discussion on this research of lecturers' work performance, working situation, achievement motivation and effective learning that is reviewed from the approach, methods, and media used by the lecturers in the teaching learning process.

In analyzing the data, quantitatively, the writer used simple regression techniques and double regression. The calculations used SPSS version 20.0 . this also obtained the calculation of descriptive statistics such as mean, standard deviation, minimum score, the maximum score and frequency distribution.

The analysis was performed to test the analytical requirements in the form of homogeneity test. Furthermore, the data were analyzed regression to determine how much influence of the working situation and achievement motivation on lecturers' work performance variables in the Faculty of 
Islamic Education and Teacher Training in IAIN Imam Bonjol Padang.

Then, Data were analyzed qualitatively as follows :

a. Data reduction, that is the selection process, the transformation of raw data obtained from the records in the field that took during the study.

b. Categorization, which is done by classifying the data interviews, observation and documentation.

c. Verification of data to draw a clear conclusion

\section{RESEARCH FINDINGS AND DISCUSSION}

As stated in the previous section, the study variables consist of two independent variables and a dependent variable. As the independent variable is the working situation and achievement motivation, while the dependent variable is work performance.

\section{Work Situation Variable}

From the analysis of the data, it can be presented the description of each variable research as the table below:

\section{Table 1: the description of Variable Data on Working Situation}

\begin{tabular}{|c|c|c|}
\hline \multicolumn{3}{|c|}{ Statistics } \\
\hline \multicolumn{3}{|c|}{ Situasi Kerja (X1) } \\
\hline & Valid & 10 \\
\hline & Missing & 0 \\
\hline $\mathrm{Me}$ & & 62,4000 \\
\hline $\mathrm{Mec}$ & & 62,5000 \\
\hline Moc & & $58,00^{a}$ \\
\hline Std & tion & 6,51835 \\
\hline Var & & 42,489 \\
\hline Min & & 53,00 \\
\hline Max & & 72,00 \\
\hline Sun & & 624,00 \\
\hline
\end{tabular}

Source: own calculation, 2013

The table shows that the average score (mean) the working situation of 62.40 with a standard deviation of 6.51. From these two figures obtained the coefficient of variation of 42.489 . The magnitude of these coefficients reflect the diversity of each variable data on working situation.

The distribution of this figure can be plotted in the form of a frequency distribution histogram score on working situation as follows: 


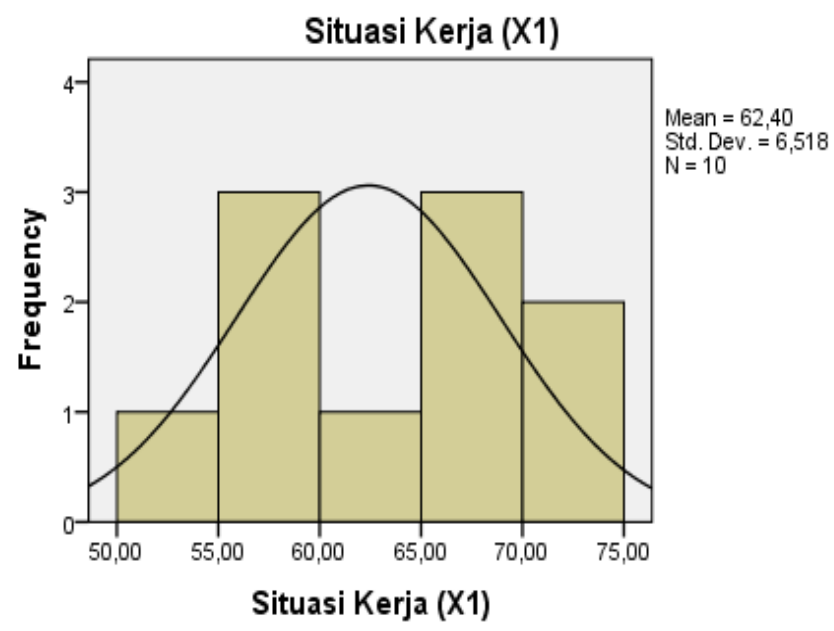

Figure 1: Frequency of Distribution Histogram Score on Working Situation

\section{Achievement Motivation Variable}

From the analysis of the data, it can be presented a description of each research variable as the following table:

Table 2: Description of Achievement Motivation Data Variable Statistics

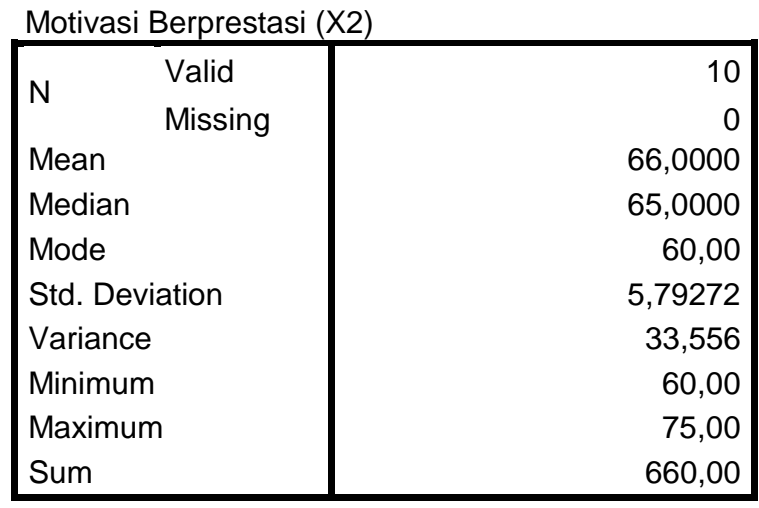

Source: own calculation, 2013

The table shows that the average score (mean) achievement motivation of 66.00 with a standard deviation of 5.79. From these two figures obtained the coefficient of variation of 33.55. The magnitude of this coefficient reflects the diversity of each data variable on achievement motivation.

The distribution of this figure can be plotted in the form of a frequency of histogram distribution on achievement motivation scores as follows: 


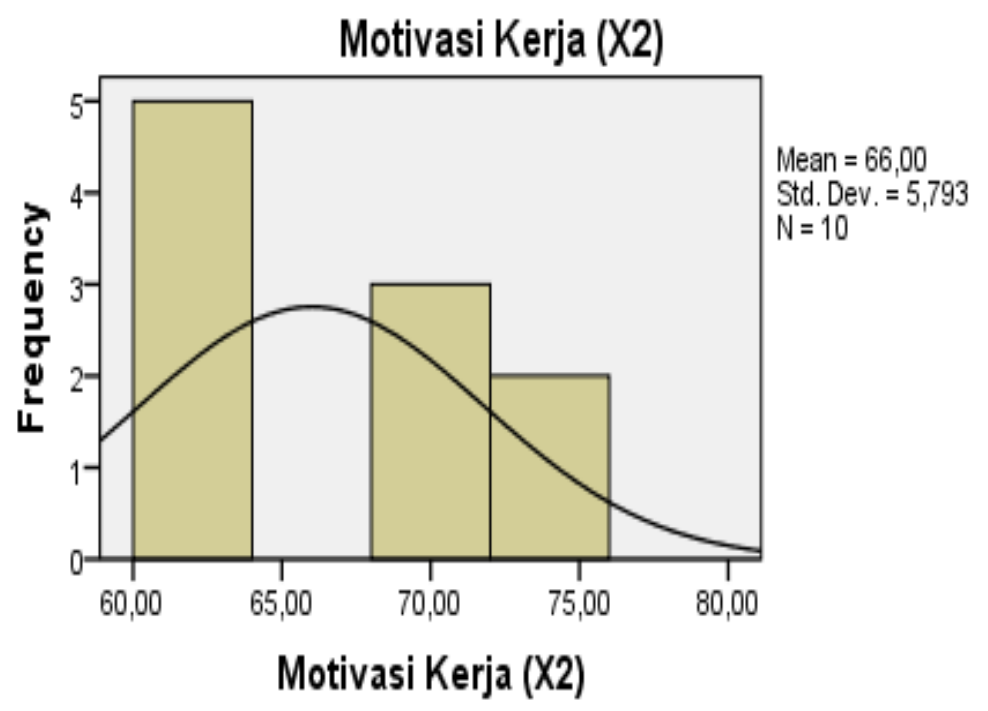

Figure 2: Frequency Distribution Histogram Score on Achievement Motivation

\section{Working Performance Variable}

From the analysis of the data, it can be presented a description of each variable research as research data processed by the table below:

\section{Table 3: Description of Work Performance Variable Data}

\section{Statistics}

\begin{tabular}{|c|c|c|}
\hline \multicolumn{3}{|c|}{ Prestasi Kerja $(\mathrm{Y})$} \\
\hline & Valid & 10 \\
\hline & Missing & 0 \\
\hline $\mathrm{Me}$ & & 64,8000 \\
\hline & & 62,5000 \\
\hline Mo & & 60,00 \\
\hline & & 5,61348 \\
\hline & & 31,511 \\
\hline & & 60,00 \\
\hline & & 75,00 \\
\hline Sur & & 648,00 \\
\hline
\end{tabular}

Source: Adapted own, 2013

The table shows that the average score (mean) performance of 64.80 with a standard deviation of 5.61. From these two figures obtained the coefficient of variation of 31.51. The magnitude of these coefficients reflect the diversity of each data variable on working performance.

The distribution of this figure can be plotted in the form of a frequency distribution histogram on achievement scores as follows: 


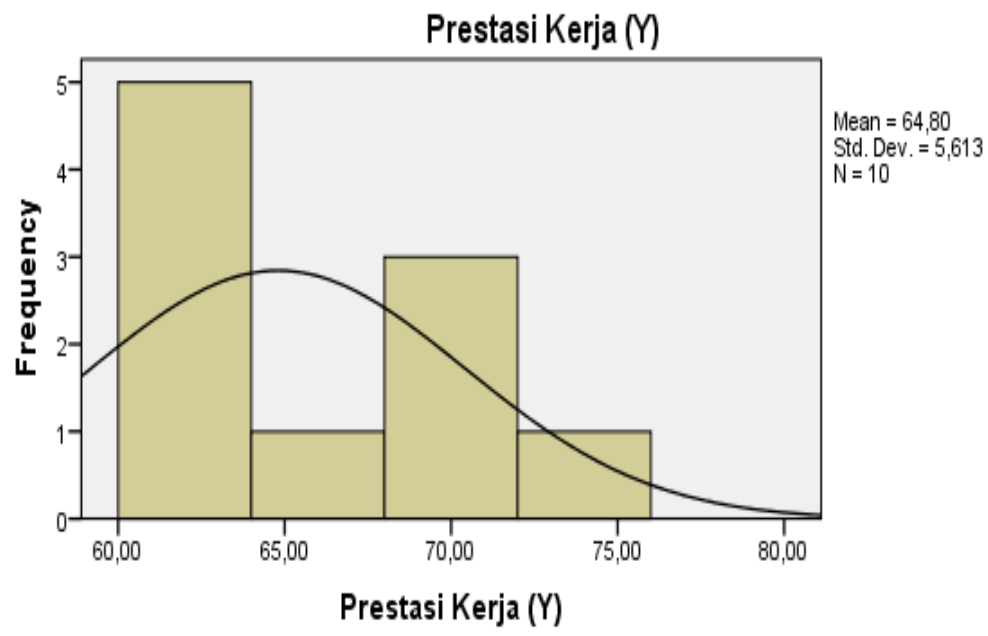

Figure 3: Frequency Distribution Histogram on work Performance Score

\section{Data Analysis}

To view estimates between independent variables with the dependent variable shown in the following regression equation:

$$
\mathrm{Y}=14.775+0,412 \mathrm{X}_{1}+0,368 \mathrm{X}_{2}
$$

14.775 is The amount of work that can be interpreted if the work situation is increased by one unit then the work performance variables tend to increase as well by 0.412 units. The amount of 14.775 can be interpreted if achievement motivation increases by one unit, the variable performance is also likely to increase by 0,368 units.

\section{Hypothesis 1}

In the work situation variables, the contribution given is about 0.487 or $48.7 \%$. So, lecturers who had and felt good in working situation,would affect on their work performance as well. In other word, their work performance was also good. Furthermore, the variable of achievement motivation comtributes about 0.430 or $43.0 \%$. So, a lecturer who has a great achievement motivation, will affect the quality of their work performance.
From these results it can be concluded that each variables, the work situation and the achievement motivation, hQWas a significant effect on the work performance. Thus, the hypothesis which states that "there is significant influence between the work situation and achievement motivation individually on the performance of lecturers PAI" (Ha) is accepted. Based on these data it can be seen that in the Department of PAI Faculty of Education and Teaching in IAIN Imam Bonjol Padang there are significant effect on work situation and achievement motivation individually on work performance.

\section{Hypothesis 2}

The results of statistical tests using statistical formulas is obtained the contribution about 0.583 or $58.3 \%$ at $\alpha$ 0.05 . Thus the hypothesis which states that "a significant difference between the working situation and achievement motivation together on work performance is accepted in other word, $\mathrm{Ha}$ is accepted and Ho is rejected. It means that the work situation and achievement motivation of the lecturer PAI in any kinds of the circumstances will impact on the performance of lecturers PAI. If the work 
situation and the motivation do well,so the work performance is also good, and vice versa.

\section{Implementation Approach, Methods, and Media Services Used In Achieving Effective Study by Lecturer PAI at the Faculty of Islamic Education and Teacher Training in IAIN Imam Bonjol Padang}

Ideally, to create an effectiveness of lecturer teaching, a lecturer should pay attention to some factors, including the student's readiness to learn, what materials will be delivered and what goals to be achieved in each of the learning process.

\section{Lecturer PAI approach in achieving Effective Study}

The writer conducted interviews with some of the lecturers PAI on the approach used in creating an effective learning. At the time of the research, it is obtained information that the approach taken is for an individual approach, they used the emotional and empathy approach, and for a working group, they applied a working group students in teaching learning process. The approach taken is very closely related to the circumstances of the class because it can create a conducive situation in learning, thus it improves students' learning motivation.lectures conducted the teaching learning process by making a group discussion and if one of us had poblems in the study, he gave us a consulting time to solve those problems.

The results of the interviews with the PAI lecturers on the approach taken to obtain the effective learning are as follows:

1) Before starting the lesson, the lecturers said greeting.

2) To attract the attention of students , the lectures did apperseption in relation to the topic.
3) Then he asked the students about the previous lesson and reexplained the lessons which students did not understand yet.

Based on the interviews with one of the PAI lecturers, the writer obtained information that the lecturer commonly uses varied approaches from expository approach to the inquiry approach.

Then the results of interviews to one of the fifth semester students about the approach used by the lecturer to achieve the effective learning is as follows :

1) Before starting the lesson, lecturer did greetings.

2) Lecturer arranged students' seat.

3) Lecturer told a story that linked to the lesson

4) Lecturer asked one of the students about the previous lesson.

5) Lecturer provide reinforcement / reward to the students who answered the question correctly.

6) Lecturer repeat the previous lesson which the students did not understand yet.

Based on interviews with the lecturer who taught in the fifth semester in PAI above, it can be concluded that the lecturer was seeking the effectiveness of learningby giving varied approaches to achieve the maximum learning outcomes.

The Interview with one of the fifth semester students on the approach used to achieve efective learning is as follows:

1) The lecturer took the attendance of the students, greeted them and prayed

2) The lecturer review the previous lesson by asking to the students

3) The lecturer asked to submit the task assigned last week

4) The lecturer let the students dicuss the topic at the moment

5) The lecturer paied attention on the discussion, gave explanation on doubtful question and concluded the topic at the time 
The other interview with the other lecturers of PAI, the approach used in the classroom was PAKEM (Active, creative, efective and fun Learning ). From the observation, it is shown that the students were asked to work in pair with the friend next seat to solve the given problem and asked to presented in front of the class. Then, the other groups should response to the result of that presentation simultaneously ; the faster the group responsed, the higher the score was. Also, it was seen that the students enjoyed the learning process

Based on the observation to PAI lecturers who taught in the third semester about the use of the approach to achieve the efective learning is as follows :

1) the class began with basmalah, discussed the previous lesson, asked about the students' comprehension on that lesson.

2) Lecturer gave an illustration on a case occured in religious life.

3) Lecturer asked students to find other examples of Islamic law in everyday life.

4) Lecturer began a class discussion by asking the choosen group to present their paper in front of the class.

5) Lecturer followed the discussion and asked all the students to participate in the discussion.

6) The unclear answers were described by the lecturer at the end of the discussion

7) Lecturer gave the task for next week.

The other interviews is held to junior lecturers. It is found that the approach applied in the learning is andragogics approach, namely the didactic approach through reinforcement skills. Students are always pushed to create the concept in their mind that helped to increase their motivation to learn.
Thus, it can be concluded that the approach employed by the lecturers in PAI can be regarded as effective learning approach. It means that the lecturer didnot applied monotonous approaches. They varied the approaches. Then, prior to the learning process, the lecturer firstly create a condusive classroom atmosphere, so the learning process became effectively and efficiently.

The lecturer also arouse the curiosity of students by providing an illustration relating to the topic of the lesson and linking the subject matter with students' daily life in an emotional approach. In other words, the lecturers gave the lecture in order it can affect the students' life in their surrounding, so that the learning became meaningful. This can be called as a constructive learning.

\section{The method applied by PAI Lecturer for effective learning}

Ideally, a study can be said to be effective if teachers can take advantage of all the learning components as well as possible including the teaching methods which are appropriate to the circumstances of students as learners, to the lesson given, to the situation of the class, to the method used and also to the orientation of the learning objectives.

The Interviews held with the lectures in PAI show that the method used was the combination of the existing methods, namely lectures, question and answer with students, assignments, problem solving, and peer tutoring.

From the interview with another lecturer, it was seen that the lecturers who taught tafsir , interpretation of Al Qur an, utilize stories methods that are relevant to the subject matter. The writer interviewed directly and he claimed he had applied this method for a long period. 
Based on the Interview with one of the fifth semester students on the approach used to achieve efective learning is as follows:

1) In giving a lecture, the lecturer explained the topics that would be studied orally.

2) Then, the lecturer explained on the purpose of the lesson at the time.

3) Lecturer divided the students into some group discussion

4) Lecturer followed the discussion with some problems arouse at the discussion

5) the lecturer asked some students to practice in front of the class if the lesson was related to practical

6) the Lecturer reexplained about the issues which have not been understood yet.

7) The lecturer assigned tasks to the students

Based on the interview done by the writer to one of the fifth semester students about the teaching method applied by the lecturers in PAI to achieve the efective learning, it can be seen as follows :

1) In giving a lecture, the lecturer explained the topics that would be studied orally at that moment.

2) Then, the lecturer explained on the purpose of the lesson at the time.

3) Lecturer divided the students into some group discussion and asked some students to practice in front of the class

4) the Lecturer reexplained about the issues which have not been understood yet.Then, The lecturer assigned tasks for the students

Based on the interviews and the observations that has been done to the PAI lecturers and students, it can be concluded that the learning methods used by lecturers are considered into an effective learning method,it means that at first, all lecturers focus on student learning materials by explaining verbally about the topics and learning objectives to be learned on that day, then the lecturer told students to be active in group discussions and student told about what they knew in the group discussion and others responded. Thus, theoretically the method used by the PAI lecturers is active learning method that combines with several methods of learnin. This method made the students became more active and lecturers as a facilitator in the learning process. This will thus make learning more effective and efficient so that the goal can be achieved.

This is suitable with the creation of the working situation and the achievement motivation of the lecturers on campus. Therefore, it gives a very significant influence on work performance of the lecturer in creating effective learning in the Department of PAI.

\section{Media used by PAI Lecturer in effective learning}

The Interviews was conducted on Tuesday October 15 , 2013, the writer obtained information that the medium used in teaching learning process was printed media such as papers, and sometimes used the LCD because electricity was often off on campus. It seem that the students prefer LCD used as a multimedia because they looked enthusiastic while in learning process.

Based on interviews with one of the lecturers in PAI on the media used to achieve effective learning is as follows:

1) In the process of learning, PAI lecturer used the LCD on the lecturing.

2) PAI Lecturer asked the students to listen and gave examples of each. 
3) Lecturer distribute hand out from the Internet to support the learning material.

4) Lecturer still used the blackboard as a tool in delivering course materials to students in the form of schemes.

5) PAI Lecturer used stationary objects such as dolls for modeling the material organization of the bodies, prayer rugs, mukenah, gloves in the material practice of worship.

The Interview with a fifth semester student on learning media used to achieve effective learning is as follows:

1) In the process of learning the lecturer used a laptop , LCD, and blackboard to explain the lesson generally in the form of mindmap.

2) PAI Lecturer asked students to present their paper and explained about it.

3) Sometimes the lecturer asked the students to watch the issue occured in surrounding the campus, for example, to observe the behavior of students around campus.

Based on interviews with the lectures teching in fifith semester in PAI about media used to increase the effectiveness of learningis as follows :

1) In the process of learning, the PAI lecturer distributed the handout about the issues on education and the chaiman of the class copied for all the students.

2) PAI Lecturer sent one student standing in front of the class to explain the content of learning material.

3) PAI Lecturer utilized blackboard as a teaching tool in conveying the lesson.

4) Lecturer asked students to share the papers' group to the others.
Based on interviews conducted by the writer with one of the students on media used to achieve effective are as follows :

1) Lecturer asked students to read the yellow book that was brought into the classroom.

2) Lecturer asked other students to listen and corrected the wrong readings.

3) Lecturer asked students to write verses to the front of the class.

4) Lecturer utilized the whiteboard as a tool in writing dalil to be memorized by students.

Based on interviews and observations that has been done with PAI faculty and students, the writer concludes that the instructional media used by lecturers PAI were quite varied. This certainly can attract the attention of students so that the learning process can run well. To create an active learning process and effective must be supported by all components of learning and ultimately will result in an effective and efficient learning.

PAI lecturers used media from the printed media to the electronic media. This is enough to make students interested in. Yet, the monotonous media will be less attractive to the students. Based on observations and interviews that have been conducted to several lecturers and students of PAI, it shows that when the motivation of lecturers in teaching was good, it can prove the high performance of the lecturers were also good, then the effective learning was achieved.

By looking at the distribution of data from previous studies, it can be said that the influence established between work situations and achievement motivation together on the performance of PAI lecturer Faculty of Education and Teaching in IAIN Imam Bonjol Padang obtained at 0.583. It also can be seen that the value of the 
regression coefficient between the variables jointly acquired by 14.775 and significance values for obtained observation probability for 0,047 . When the value of the coefficient probability compared with the level of $\alpha=$ 0.05 , it was taken as fault tolerance limit, then the value of the significance probability is smaller than level $\alpha=0.05$.

Based on these descriptions, it is known that the hypothesis $\mathrm{HO}$ is rejected with the statement that there is a significant influence between the variables of the working situation and achievement motivation jointly on the performance of PAI lecturer in Faculty of education and Teaching in IAIN Imam Bonjol Padang. This shows that the working situation and achievement motivation owned by PAI lecturer in Faculty of Education and Teaching IAIN in Imam Bonjol Padang significantly affect their work performance.

Work situation and achievement motivation owned by PAI lecturers can be seen from how they get the work done in accordance with the demands in himself, so that learning objectives can be achievedas well.

Furthermore, a significant difference between the working situation variable (X1) on work performance variables (Y). Thus, it can be said that the working situation owned by PAI lecturers gives significant effect on their work performance.

Some ways that can be done by lecturers PAI in improving their performances are to create a positive and fun situation at work. Good lecturers should always be able to create a work situation that is conducive to work so that later it gives a positive impact on their work performance in the future.

It can be concluded that the better the employment situation created by the lecturers, the higher the performance would be achieved. Without a good working situation, it is difficult for the campus to achieve optimal results. Thus, to improve their work performance, it can be done by optimizing and creating a conducive situation in teaching and in the campus environment.

In terms of achievement motivation,it is found that there is a significant relationship between the variables of achievement motivation (X2) with work performance variable (Y). Thus, it can be said that the achievement motivation owned by lecturers effect on their work performance.

In improving work performance, PAI lecturer must pay attention to their achievement motivation in doing activities on campus. The more their achievement motivation is owned, the more it will affect their work on campus. This is in line with the views expressed by Maier cited by As'ad (1995) which states that a person's work performance is successful in carrying out the work .In other word, it can be interpreted as an effort in order to achieve better performance. Thus, increasing achievement motivation will affect their work performance.

Improving work performance of PAI lecturer Faculty of Education and Teaching in IAIN Imam Bonjol Padang can be proved that the lecturers through the approach taken in the study, both are individuals approaches and groups approaches. In addition, the learningis used the inquiry and expository approach and the approaches are always educative, such as andragogics approach that aims to establish the potential of the student so that it always motivates them to learn.

Furthermore, a good work performance of the lecturer can be seen from the method used in creating a conducive learning process. Either in the form of conventional methods, lectures, 
question and answer, assignment, or using methods that activate the students in the lecturing, stories are also used as media in religious materials. It is very attractive to students because it can figure out clearly about the history of Islam.

Lecturer work performance is also used a variety of creative media in learning. commonly it was found that the PAI lecturer used visual media, whiteboard, discussion papers, printed books. For electronic media, it depended on the electrical conditions which was often off. Thus, the learning process is interrupted so that the tendency of PAI lecturers used only visual media such as discussion paper.

\section{CONCLUSION}

Based on the results of studies using the mixed method, it can be concluded as follows:

1. The situation of work and achievement motivation individually affect the performance of the lecturers of the Department of PAI Faculty of Education and Teaching in IAIN Imam Bonjol Padang. Work situation contributes the effect of $48.7 \%$ on the performance and motivation lecturer gives a contribution of $43.0 \%$ on the performance of the lecturer.

2. Situation of work and achievement motivation jointly affect the job performance of $58.3 \%$. This means that the work situation and achievement motivation of good lecturers will give a good effect and also contribute to the achievement of their work at the Department of PAI Faculty of Education and Teaching in IAIN Imam Bonjol Padang.

3. The learning approach used is expository, inquiry, and emotional approach. The lecturers Also used PAKEM approach and the approach are andragogy, which combines several methods of learning. methods applied in learning are multimethode in the form of active learning which creates the more active students and the lecturers as a facilitator in the learning process so that the learning objectives can be achieved effectively and efficient.

PAI lecturers used media, printed media,a discussion paper ,the electronic media.the use of monotonous media necessarily will less attractive to them. The good approach, methods, and media used by PAI lecturers can certainly improve their work performance in realizing effective and efficient learning.

\section{REFERENCES}

Al-quran dan Terjemahan. (2008). Jakarta: Departemen Agama RI.

Anoraga, P. (2002). Perilaku Keorganisasian. Jakarta: PT Melton Putra.

Arikunto, S. (2000). Prosedur Penelitian. Jakarta: Rineka Cipta.

Benton, W. (1974). The New Encyclopedia Britinica. London Encyclopedia.

Danim, S. (2004). Motivasi Kepemimpinan \& Efektivitas Kelompok. Jakarta: PT Rineka Cipta.

Depdiknas. (2001). Kamus Umum Bahasa Indonesia, Jakarta : Balai Pustaka.

Djamarah, S. B. (2006). Strategi Belajar Mengajar, Jakarta: Rineka Cipta.

Gibson, J. L., Ivancevich \& Donelly. (1992). Organization. New York: Business Publication, Inc.

Hamalik, O. (2003). Kurikulum dan Pembelajaran, Jakarta: Bumi Aksara.

Manullang. (2004). Manajemen Personalia. Jakarta: Ghalia Indonesia. 
Milton, C. R. (1981). Human Behavior Organization, Englewood Cliffs: Prentice - Hall Inc.

Mitrani. (2005). Manajemen SDM Berdasarkan Kompetensi. Dalziel (ed). Jakarta: Intermasa.

Mulyasa, E. (2003). Manajemen Berbasis Sekolah. Bandung: PT. Remaja Rosda Karya.

Nitisemito, A. (2002). Manajemen Personalia Sumber Daya Manusia. Jakarta: Ghalia Indonesia.

Popham, W. J. \& Baker, E. L. (1992). Teknik Mengajar secara Sistematis, Jakarta: PT Rineka Cipta.

Ramayulis. (2006). Ilmu Pendidikan Islam . Jakarta: Kalam Mulia, cet.ke-V.

Shihab, M. Q. (2002). Tafsir Al-Mishbah Pesan, Kesan dan Keserasian AlQuran, Jakarta: Lentera Hati.
Siagian, S. P. (2005). Manajemen Sumber Daya Manusia. Jakarta: Bumi Aksara.

Steers, R. (2000). Motivation \& Work Behavior. New York: Mc Graw Hill Book Co.

Surya, M. (2003). Psikologi Pembelajaran dan Pengajaran, Jakarta: Maha putra Adi Karya.

Timpe, A. D. (2003). Kinerja, Alih bahasa: Syofyan Cikmat, Jakarta: PT. Gramedia, Pustaka Utama.

Wijaya. (2006). Ilmu komunikasi. Jakarta: Rineka Cipta.

Wrag, T., Dunne., \& Richard. (1996). Pembelajaran Efektif, Jakarta: PT Gramedia. 